\title{
Minimally processed yellow melon enriched with probiotic bacteria
}

\section{Melão minimamente processado enriquecido com bactéria probiótica}

\author{
Patrícia Martins de Oliveira ${ }^{1 *}$; Bruno Ricardo de Castro Leite Júnior ${ }^{2}$; \\ Maurilio Lopes Martins; ${ }^{3}$ Eliane Maurício Furtado Martins ${ }^{3}$; Afonso Mota Ramos ${ }^{4}$
}

\begin{abstract}
The demand for healthy diets with fresh foods, especially minimally processed fruits and vegetables, resulted in a variety of products available to consumers. The nutritional benefits of probiotic lactic acid bacteria contribute to increase consumption of minimally processed vegetables enriched with these microorganisms in supermarkets and restaurants, since the modern consumer search products of high functionality and safety. The aim of this study was to assess the viability of Lactobacillus rhamnosus HN001 on minimally processed yellow melon and determine the microbiological and physicochemical properties of this food. The counts of L. rhamnosus were above $10^{8} \mathrm{CFU}^{-1}$, and the microbiological quality of melons was safe to consumers. The $\mathrm{pH}$ lowered and the acidity increased over time in minimally processed melons. The soluble solids did not differ between samples. The color coordinates $\mathrm{L}^{*}$ and $\mathrm{a}^{*}$ have not changed and melon firmness decreased over time. The scanning electron microscopy revealed adhesion of L. rhamnosus HN001 on the surface of treated melon. Despite some physicochemical changes, the production of minimally processed melon enriched with L. rhamnosus is feasible transforming it into a potential vehicle for probiotics.
\end{abstract}

Key words: Fruits, minimally processed, Lactobacillus rhamnosus, functional food, non-dairy products

\section{Resumo}

A demanda por uma alimentação saudável com alimentos frescos, especialmente frutas e hortaliças minimamente processadas, resultou em uma variedade de produtos disponíveis para os consumidores. Os benefícios nutricionais de bactérias láticas probióticas contribuem para aumentar o consumo de vegetais minimamente processados enriquecidos com estes micro-organismos em supermercados e restaurantes, uma vez que o consumidor moderno busca produtos de alta funcionalidade e segurança. O objetivo deste estudo foi avaliar a viabilidade de Lactobacillus rhamnosus HN001 em melão minimamente processado e determinar as propriedades microbiológicas e físico-químicas desse alimento. As contagens de $L$. rhamnosus estavam acima $10^{8} \mathrm{UFC}^{-1}$ e a qualidade microbiológica dos melões estava segura para os consumidores. $\mathrm{O}$ pH diminuiu e a acidez aumentou ao longo do período de estocagem dos melões minimamente processados. Os sólidos solúveis não diferiram entre as amostras. As coordenadas de cor $\mathrm{L}^{*}$ e a * não mudaram e a firmeza do melão diminuiu ao longo do tempo. A microscopia eletrônica de varredura revelou a adesão de L. rhamnosus HN001 na superfície do melão tratado. Apesar de algumas alterações físico-químicas, a produção de melão minimamente processado enriquecido $\operatorname{com} L$. rhamnosus é viável e transforma-o em um potencial veículo de probióticos.

Palavras-chave: Frutas minimamente processadas, L. rhamnosus, alimentos funcionais, produtos não lácteos

\footnotetext{
${ }^{1}$ Discente do Curso de Mestrado em Ciência e Tecnologia de Alimentos, Universidade Federal Viçosa, UFV, Viçosa, MG, Brasil. E-mail: patriciariopomba@yahoo.com.br

2 Discente do Curso de Doutorado em Tecnologia de Alimentos, Universidade Estadual de Campinas, UNICAMP, Campinas, SP, Brasil. E-mail: brunorclj@gmail.com

3 Profs. do Dept ${ }^{\circ}$ de Ciência e Tecnologia de Alimentos do Instituto Federal de Educação, Ciência e Tecnologia do Sudeste de Minas Gerais, Câmpus Rio Pomba, Rio Pomba, MG, Brasil. E-mail: maurilio.martins@ifsudestemg.edu.br; eliane.martins@, ifsudestemg.edu.br

${ }^{4}$ Prof., Dept ${ }^{\circ}$ de Tecnologia de Alimentos, Universidade Federal de Viçosa, UFV, Viçosa, MG, Brasil. E-mail: amramos@ufv.br

* Author for correspondence
} 


\section{Introduction}

Minimally processed (MP) fruits represent one of the most rapidly expanding segments of the lightly treated refrigerated food market owing to their increased functionality. Minimal processing offers consumers highly nutritious, convenient and healthful fruits while maintaining freshness of the non-processed products (WU; ZHANG; WANG, 2012). According to Silva et al. (2007), minimally processed fruits and vegetables are products that have undergone cleaning, washing, selection, peeling and cutting, to obtain a $100 \%$ usable product that is packaged and maintained under refrigeration.

Melon is a kind of fruit having a big market share in minimally processed products (SUPAPVANICH; TUCKER, 2011). Besides, this fruit is cholesterol free and it contains vitamin B1, B2, PP, A and $\mathrm{C}$, being a fruit widely produced and consumed worldwide (NICOLAIS et al., 2011).

There is a consensus among researchers that the consumption of adequate amounts of fruits and vegetables is a key factor in a healthy diet (OMS-OLIU; SOLIVA-FORTUNY, 2011). These products contain significant levels of functional nutrients, such as fiber, vitamins, minerals and bioactive compounds, which assist in improving an individual's health and nutritional status. Thus, the consumption of food enriched with physiologically active components, such as probiotics (MARTINS et al., 2013), has led the industry to develop alternative products capable of improving health and wellness (MARK-HERBERT, 2004).

Probiotic dairy products are well established and recognized by most consumers as healthy. However, since many people are allergic or intolerant to these products, the consumption of fruits containing probiotic bacteria could be an alternative for these consumers (RIVERA-ESPINOZA; GALLARDONAVARRO, 2010; MARTINS et al., 2013). In addition to providing probiotic microorganisms to the consumer, fruits with probiotic bacteria contain nutrients beneficial to health and may positively influence the viability of probiotics (YOON; WOODAMS; HANG, 2004; RANADHEERA; BAINES; ADAMS, 2010).

Lactic acid bacteria are considered challenging microorganisms due to the essential amino acids and vitamins requirements for their growth (SALMINEN; VON WRIGH, 1998). Rodgers (2008) related that adding lactic acid bacteria to restaurant meals, such as vegetable salad, is a novel concept for the general public and food service professionals. Thus, the nutritional benefits of probiotic bacteria have motivated the increased consumption of minimally processed vegetables in supermarkets and restaurants. Such benefits may be assigned to the control and stabilization of the intestinal microbiota after the use of antibiotics (SOCCOL et al., 2010), increased gastrointestinal resistance to colonization by pathogens (ZHANG et al., 2011), competition for nutrients and adhesion sites (FERREIRA, SILVA, 2010; SAAD; BEDANI; MAMIZUKA, 2011), among others.

Raw food products have recently been intensively investigated as potential substrates for the production of probiotic non-dairy foods (MARTINS et al., 2013; SOCCOL et al., 2010; CETIN, 2011; PERES et al., 2012; YU et al., 2012). Alegre et al. (2011) and Rößle et al. (2010a; 2010b) found that probiotic strains have the ability to grow in fruit matrices due to fruit nutritional content and internal tissue structures. Therefore, this study aimed to evaluate the viability of Lactobacillus rhamnosus HN001 in minimally processed yellow melon and to determine their microbiological and physicochemical characteristics during storage.

\section{Material and Methods}

\section{Preparation of probiotic culture}

The culture of L. rhamnosus HN001 was prepared according to Rößle et al. (2010a). Briefly, the probiotic culture was activated twice in Man Rogosa Sharpe (MRS) broth and incubated at 
$37^{\circ} \mathrm{C}$ for $18 \mathrm{~h}$. Afterwards, the probiotic culture was activated in MRS broth for $16 \mathrm{~h}$, then centrifuged at $5{ }^{\circ} \mathrm{C}$ for 15 minutes at $7000 \mathrm{~g}$. The supernatant of the culture medium was discarded and the probiotic cell pellet was aseptically resuspended in a buffer solution of citric acid:sodium citrate at a 1:1 ratio and $\mathrm{pH} 6.2$ at a ratio of 1:10; i.e., for every gram of cells, $10 \mathrm{ml}$ of buffer solution was added to obtain at least $10^{10}$ cells $\cdot \mathrm{mL}^{-1}$.

\section{Minimal processing of melon and inoculation with}

\section{L. rhamnosus}

The melons, yellow type (Cucumis melo L.), were acquired in the Rio Pomba market, Minas Gerais State, Brazil. They were initially washed with potable water and sanitized in chloride solution with $200 \mathrm{mg} \mathrm{L}^{-1}$ of active choride for $15 \mathrm{~min}$ at $5{ }^{\circ} \mathrm{C}$. After sanitizing, melon fruits were rinsed in chloride solution $20 \mathrm{mg} \mathrm{L}^{-1}$ for $5 \mathrm{~min}$. Then, they were peeled, all seeds were removed and the fruits were cut into cubes of approximately $2 \mathrm{~cm}$ x $2 \mathrm{~cm}$.

The melon cubes after cutting were immersed for $10 \mathrm{~min}$ in a solution citric acid:sodium citrate at a $1: 1$ ratio and $\mathrm{pH} 6.2$ containing approximately $10^{10} \mathrm{CFU} \cdot \mathrm{mL}^{-1}$ of L. rhamnosus HN001. Thus, to obtain minimally processed melon containing probiotic culture, $1 \mathrm{ml}$ of the previously prepared probiotic cell solution was added for each gram of melon cubes, i.e., the ratio was $1 \mathrm{~mL}$ of probiotic solution for each gram melon. Subsequently, minimally processed melons were drained for 3 minutes, in domestic drainer, to remove excess of $L$. rhamnosus HN001 solution. The control treatment was immersed for $10 \mathrm{~min}$ in a buffer solution of citric acid:sodium citrate at a $1: 1$ ratio and $\mathrm{pH} 6.2$ without inoculation of L. rhamnosus.

Minimally processed melons inoculated with L. rhamnosus HN001 and control were packed in polyethylene tereftalato (PET) boxes and stored at $6{ }^{\circ} \mathrm{C}$ and $15{ }^{\circ} \mathrm{C}$ for $0,48,96$ and $120 \mathrm{~h}$ to monitor shelf life. All experiments were performed in three replicates.
Assessment of L. rhamnosus viability on minimally processed melon

The viability of L. rhamnosus HN001 on minimally processed melons was assessed, in triplicate, by colony counting using pour plate method in Rogosa Agar SL (HIMEDIA, India), a selective agar used for lactobacilli enumeration, after $0,48,96$ and $120 \mathrm{~h}$ of storage at $6{ }^{\circ} \mathrm{C}$ and $15^{\circ} \mathrm{C}$. The Petri dishes were incubated in anaerobic jars at $37^{\circ} \mathrm{C}$ for $72 \mathrm{~h}$.

\section{Determination of the microbiological characteristics}

Evaluations of fecal coliforms and Salmonella sp. are required by the National Agency of Sanitary Surveillance (ANVISA) as part of the Brazilian Health Ministry in the legal resolution RDC No. 12 (BRASIL, 2001). Based on these microbiological requirements, the Most Probable Number (MPN) method was used to determine fecal coliforms per gram of minimally processed melon (KORNACKI; JOHNSON, 2001). Also, analysis of Salmonella sp. in $25 \mathrm{~g}$ of sample from all treatments was done according to Andrews et al. (2001). All analyzes were carried out in triplicate.

\section{Determination of physicochemical characteristics}

Analyses of $\mathrm{pH}$, acidity in citric acid and total soluble solids (TSS) in the minimally processed melons inoculated with L. rhamnosus HN001 and of the control treatment were conducted, in triplicate, according to AOAC (AOAC, 1997).

\section{Colorimetric analysis}

The surface color of minimally processed melons inoculated with L. rhamnosus HN001 and control was evaluated, in triplicate, using the colorimeter MiniScan EZ System (HunterLab, Reston, VA). Colorimetric analysis was performed by direct reading in reflectance mode of the $\mathrm{L}^{*}$, $a^{*}, b^{*}$ coordinates using the CIELAB L* scale, as 
this scale has been adopted as the standard by the International Commission on Illumination. Three readings were done for each specimen, taken at different points of the fruit sample in order to obtain an average value.

\section{Firmness analysis}

The firmness of minimally processed melons inoculated with L. rhamnosus HN001 and of the melons of the control treatment was determined in triplicate by compression test with 5 melon cubes using a texturometer (CT3/BrookField). A fruit sample was placed on a flat surface and compressed for 1 second with a cylindrical probe (diameter of $5 \mathrm{~cm}$ ). The fruits were analyzed at a distance of 5 $\mathrm{mm}$, with a compression speed of $5 \cdot \mathrm{mm} \mathrm{s}^{-1}$.

\section{Scanning electron microscopy (SEM)}

The minimally processed melons inoculated with L. rhamnosus HN001 and the melons of the control treatment were analyzed with the Scanning Electron Microscope (SEM, model Zeiss LEO 1430 VP, Cambridge, England) immediately after the minimal processing $(0 \mathrm{~h})$ and after $120 \mathrm{~h}$ of storage at $6{ }^{\circ} \mathrm{C}$ to evaluate the adhesion of the cell to the fruit tissue. Analyses were performed in triplicate.

Fruit samples were sliced into sections of $0.5 \mathrm{~cm}$ x $0.5 \mathrm{~cm}$ with approximately $1-2 \mathrm{~mm}$ of thickness. Slices of fruit were fixed with a mixture of $5 \%$ glutaraldehyde and a sodium phosphate buffered (PBS) solution $\left(0.1 \mathrm{~mol} \cdot \mathrm{L}^{-1}\right)$ at a ratio of $1: 1$ for $18 \mathrm{~h}$ at $7{ }^{\circ} \mathrm{C}$. Samples were washed with PBS buffer $0.05 \mathrm{~mol} \mathrm{~L}^{-1}$ (pH 7.2) for $10 \mathrm{~min}$. Samples were dehydrated with a series of acetone treatments at concentrations of $30,50,70$ and $90{ }^{\circ} \mathrm{GL}$ for $10 \mathrm{~min}$ each, then treated three times in acetone at $100{ }^{\circ} \mathrm{GL}$ for $10 \mathrm{~min}$. Fruit samples were transferred to the critical point dryer (CPD020 model, Balzers Liechstenstein) for total sample dehydration. Dried samples were metalized using an FDU 010 metalizer
(Bal-Tec, Balzers Liechstenstein) for further SEM observation and images analysis in field 6 .

\section{Statistical analysis}

Data were analyzed by completely randomized design in sub-plots divided by treatments, time and temperature. The data was analyzed using the Tukey test and regression analysis at $5 \%$ of probability. The statistical analyses were carried out using the STATISTICA 7.0 software-(StatSoft, Inc., Tulsa, Okla., U.S.A.).

\section{Results and Discussion}

Viability of L. rhamnosus in minimally processed melon

Lactobacillus rhamnosus HN001 was found to be above $10^{8} \mathrm{CFU} \cdot \mathrm{g}^{-1}$ in minimally processed melons stored at $6{ }^{\circ} \mathrm{C}$ and $15^{\circ} \mathrm{C}$ during the storage time and no significant difference was observed over time at different temperatures (Table 1). The efficacy of addition of probiotic bacteria in foods depends on the cell concentration of the inoculum and their viability that must be maintained during the shelf life of the product independent of food matrix (BERNARDEAU et al., 2008). To observe a beneficial effect in humans, the population of viable probiotic bacteria should range $10^{6}-10^{10} \cdot \mathrm{CFU} \cdot \mathrm{mL}^{-1}$ or $\mathrm{g}^{-1}$ (GIALAMAS et al., 2010). The recommendation of the National Agency of Sanitary Surveillance (ANVISA) is an intake of a minimum of $10^{8}$ to $10^{9} \mathrm{CFU} \cdot$ day $^{-1}$ of viable microorganisms (BRASIL, 2008). Thus, minimally processed melon can be a new alternative as the carrier of probiotic microorganisms. Therefore, a package containing $100 \mathrm{~g}$ of minimally processed probiotic melon offers the consumer a population above $10^{10} \mathrm{CFU} \cdot \mathrm{g}^{-1}$, sufficient quantity of bacteria to promote benefits to the host organism (DAVE; SHAH, 1997; SAAD, 2006). 
Table 1. Viability of L. rhamnosus HN $001(\mathrm{n}=3)$ in minimally processed melon.

\begin{tabular}{ccc}
\hline \multirow{2}{*}{ Time $(\mathrm{h})$} & \multicolumn{2}{c}{ Counts of minimally processed melon inoculated with $L$. rhamnosus $\log \left(\mathrm{CFU} \cdot \mathrm{g}^{-1}\right)$} \\
\cline { 2 - 3 } & $6{ }^{\circ} \mathrm{C}$ & $15^{\circ} \mathrm{C}$ \\
\hline 0 & $9.12 \pm 0.38^{\mathrm{aA}}$ & $9.12 \pm 0.38^{\mathrm{aA}}$ \\
48 & $8.90 \pm 0.05^{\mathrm{aA}}$ & $9.10 \pm 0.20^{\mathrm{aA}}$ \\
96 & $8.94 \pm 0.09^{\mathrm{aA}}$ & $9.13 \pm 0.25^{\mathrm{aA}}$ \\
120 & $8.74 \pm 0.18^{\mathrm{aA}}$ & $8.74 \pm 0.09^{\mathrm{aA}}$ \\
\hline
\end{tabular}

$\mathrm{CFU}=$ Colony Forming Units. Different lowercase letters mean significant difference $(\mathrm{p}<0.05)$ between the temperatures and different capital letters mean significant difference $(p<0.05)$ between the times.

Source: Elaboration of the authors.

Rößle et al. (2010a) used L. rhamnosus GG in minimally processed apples and found that after 10 days of storage the product contained $10^{8} \mathrm{CFU} \cdot \mathrm{g}^{-1}$ of $L$. rhamnosus, indicating the potential use of probiotic cultures in products of vegetal origin. Furthermore, Rößle et al. (2010b) used this lactobacilli strain on minimally processed apple added with oligofructose and inulin to obtain a potentially symbiotic product. They found that minimally processed apple contained approximately $10^{7} \mathrm{CFU} \cdot \mathrm{g}^{-1}$ of L. rhamnosus GG after 14 days of storage, which is enough to exert a beneficial effect on the host organism, compared to the results obtained for probiotic dairy products.

\section{Determination of microbiological characteristics}

The resolution $\mathrm{RDC}^{\circ} .12$ by ANVISA(BRASIL, 2001) set as standard the maximum counting of fecal coliforms at $5.0 \times 10^{2} \mathrm{MPN}$ per gram of fruit and the absence of Salmonella spp. in $25 \mathrm{~g}$ of sample. Thus, according to Brazilian legislation, the minimally processed melon inoculated with L. rhamnosus met the established microbiological requirements, with the results of fecal coliforms being less than $0.3 \mathrm{MPN} \cdot \mathrm{g}^{-1}$ after 120 hours of storage at $6^{\circ} \mathrm{C}$ and $15^{\circ} \mathrm{C}$. However, the control treatment was improper for human consumption after $96 \mathrm{~h}$ storage at $15^{\circ} \mathrm{C}$, with a count of fecal coliforms above $1100 \mathrm{MPN} \cdot \mathrm{g}^{-1}$, as this value exceeds the limit set by Brazilian law. This result showed the importance of storage temperatures for the preservation of minimally processed vegetables. In addition to the action of lactic acid bacteria in preventing the growth and activity of undesirable microorganisms due to its great diversity of mechanisms of action, such as the production of organic acids, bacteriocins, hydrogen peroxide, diacetyl, among other compounds (PADMAJA et al., 2011). Salmonella sp. was absent in $25 \mathrm{~g}$ of all samples.

\section{Determination of Physicochemical characteristics}

The $\mathrm{pH}$ of melons was determined temperature of $21^{\circ} \mathrm{C}$. The lowest $\mathrm{pH}$ values for probiotic melons were due to live probiotic cells which multiplied and produced acid in $10 \mathrm{~mL}$ of buffer solution during the adhesion step to the initial evaluation (Time $0 \mathrm{~h})$. The $\mathrm{pH}$ value decreased in both minimally processed melon inoculated with L. rhamnosus and control samples during the storage time at 6 and $15{ }^{\circ} \mathrm{C}(p<0.05)$ with no differences between the temperatures (Figure 1). However, differences in this parameter were not observed by Rößle et al. (2010a) in minimally processed apples containing L. rhamnosus $\mathrm{GG}$ after 10 days of storage at 2 and $4{ }^{\circ} \mathrm{C}$. 
Figure 1. Changes in $\mathrm{pH}$ values as a function of storage time at $6^{\circ} \mathrm{C}$ for minimally processed melons inoculated with L. rhamnosus HN001 and control.

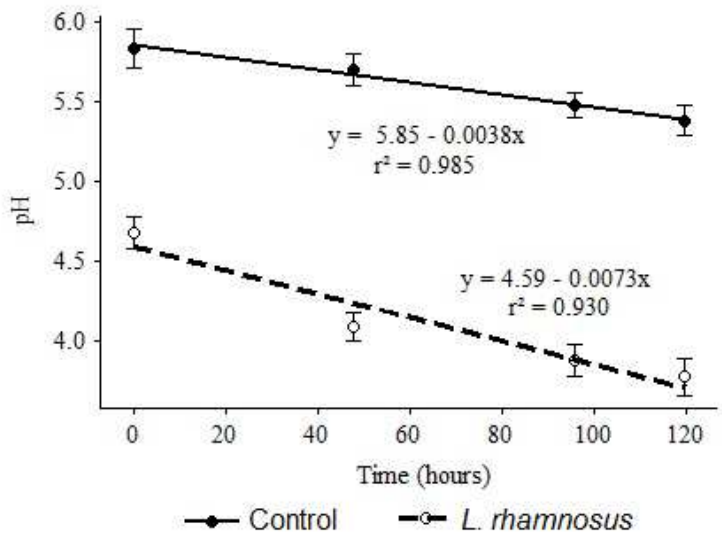

Source: Elaboration of the authors.

The acidity increased as a function of storage time for the control treatment stored at $15{ }^{\circ} \mathrm{C}$ and for minimally processed melons inoculated with L. rhamnosus stored at 6 and $15{ }^{\circ} \mathrm{C}(p<0.05)$ (Figure 2). This occurred probably due to fruit sugar degradation and consequent acid release. Alegre et al. (2011) worked with minimally processed apples inoculated with L. rhamnosus and observed differences in total acidity between control and apples inoculated with this bacterium after 7 days of storage at $10^{\circ} \mathrm{C}$.
However, there were no significant differences regarding total soluble solids $(p>0.05)$ among treatments after $120 \mathrm{~h}$ of storage at both temperatures (control $6{ }^{\circ} \mathrm{C}$ : $10.01 \pm 2.16^{\circ}$ Brix; control $15^{\circ} \mathrm{C}$ : 9.63 $\pm 1.94^{\circ}$ Brix; Melon with $L$. rhamnosus $6^{\circ} \mathrm{C}: 9.23 \pm$ $1.45{ }^{\circ}$ Brix; Melon with L. rhamnosus $15{ }^{\circ} \mathrm{C}$ : 9.59 $\pm 1.66^{\circ}$ Brix). Rößle et al. (2010a) also found no significant differences in total soluble solids content in minimally processed apples inoculated with $L$. rhamnosus and control treatment during storage.

Figure 2. Changes in acidity values as a function of storage time at 6 and $15{ }^{\circ} \mathrm{C}$ for minimally processed melon inoculated with L. rhamnosus HN001 and control.

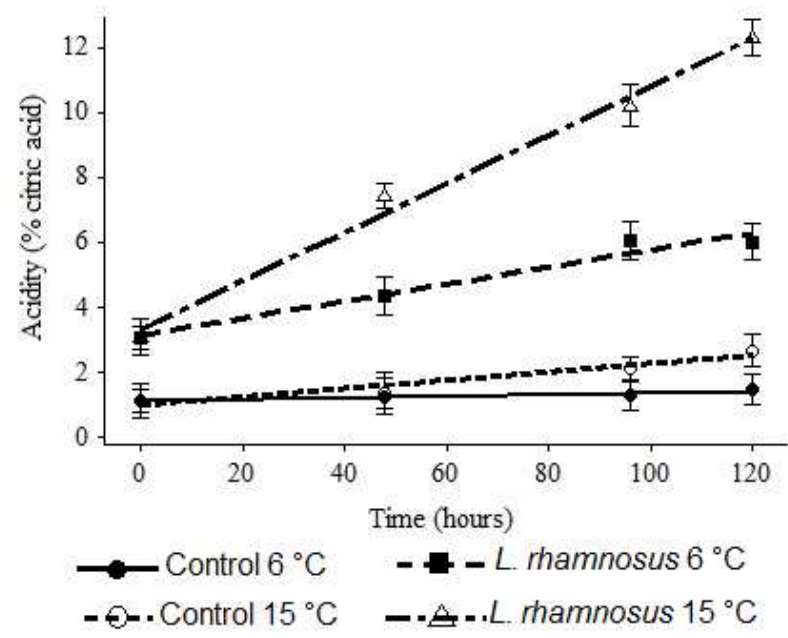

Source: Elaboration of the authors. 


\section{Melon colour}

The $\mathrm{L}^{*}$ coordinate, which represents the luminosity, was not affected $(p>0.05)$ by storage time and temperature (Table 2). However, minimally processed melon inoculated with $L$. rhamnosus presented higher average values of this parameter (lighter color) compared to control treatment. The a* coordinate, which measures the hue or color type, was not affected $(p>0.05)$ by storage time or temperature (Table 2). However, the $b^{*}$ coordinate, which represents saturation or color purity, differed significantly among treatments after 96 and $120 \mathrm{~h}(p<0.05)$. The melons inoculated with probiotic bacterial culture presented lower average values when compared with the control treatment (Table 2). In other words, the control melons showed the closest color to yellow. These results can be explained by the use of sodium citrate:citric acid buffer. This solution was used as a probiotic carrier for inoculating melon samples, and previous research indicates that citric acid can inhibit fruit browning in minimally processed fruit (ROJAS-GRAÜ; SOLIVA-FORTUNY; MARTINBELLOSO, 2009). Although control treatment has used same buffer solution, the sodium citrate:citric acid buffer solution containing the probiotic microorganism was more viscous and during the draining step it was possible that greater amount of citric acid may have been adhered in the product, reducing the browning of the fruit.

Table 2. Comparisons among treatment means $(n=3)$ of $L^{*}, a^{*}$ and $b^{*}$ coordinate values after different storage times.

\begin{tabular}{|c|c|c|c|c|c|}
\hline \multirow{2}{*}{ Treatment } & \multicolumn{4}{|c|}{ Time $(\mathrm{h})$} & \multirow[b]{2}{*}{ Regressior } \\
\hline & 0 & 48 & 96 & 120 & \\
\hline \multicolumn{6}{|c|}{$\mathrm{L}^{*}$ coordinate $\left(6^{\circ} \mathrm{C}\right)$} \\
\hline Control melon & $66.06 \pm 0.38^{\mathrm{b}}$ & $68.18 \pm 0.52^{\mathrm{b}}$ & $65.33 \pm 0.32^{\mathrm{b}}$ & $66.47 \pm 0.27^{\mathrm{b}}$ & NS \\
\hline Melon with L. rhamnosus & $68.19 \pm 0.48^{\mathrm{a}}$ & $70.69 \pm 0.21^{\mathrm{a}}$ & $67.92 \pm 0.46^{\mathrm{a}}$ & $69.85 \pm 0.57^{\mathrm{a}}$ & NS \\
\hline \multicolumn{6}{|c|}{$\mathrm{L}^{*}$ coordinate $\left(15^{\circ} \mathrm{C}\right)$} \\
\hline Control melon & $66.06 \pm 0.24^{b}$ & $67.55 \pm 0.65^{\mathrm{b}}$ & $61.30 \pm 0.21^{\mathrm{b}}$ & $65.29 \pm 0.62^{\mathrm{b}}$ & NS \\
\hline Melon with L. rhamnosus & $68.19 \pm 0.65^{\mathrm{a}}$ & $70.24 \pm 0.68^{\mathrm{a}}$ & $68.08 \pm 0.58^{\mathrm{a}}$ & $69.92 \pm 0.36^{\mathrm{a}}$ & NS \\
\hline \multicolumn{6}{|c|}{$\mathrm{a}^{*}$ coordinate $\left(6^{\circ} \mathrm{C}\right)$} \\
\hline Control melon & $-4.54 \pm 0.58^{\mathrm{a}}$ & $-3.85 \pm 0.32^{\mathrm{a}}$ & $-3.78 \pm 0.68^{\mathrm{a}}$ & $-3.87 \pm 0.46^{\mathrm{a}}$ & NS \\
\hline Melon with L. rhamnosus & $-4.03 \pm 0.39^{\mathrm{a}}$ & $-3.97 \pm 0.42^{\mathrm{a}}$ & $-2.92 \pm 0.53^{\mathrm{a}}$ & $-3.43 \pm 0.57^{\mathrm{a}}$ & NS \\
\hline \multicolumn{6}{|c|}{$\mathrm{a}^{*}$ coordinate $\left(15^{\circ} \mathrm{C}\right)$} \\
\hline Control melon & $-4.54 \pm 0.35^{\mathrm{a}}$ & $-3.59 \pm 0.53^{\mathrm{a}}$ & $-2.40 \pm 0.32^{\mathrm{a}}$ & $-2.57 \pm 0.67^{\mathrm{a}}$ & NS \\
\hline Melon with L. rhamnosus & $-4.03 \pm 0.56^{\mathrm{a}}$ & $-3.97 \pm 0.32^{\mathrm{a}}$ & $-2.92 \pm 0.59^{\mathrm{a}}$ & $-3.43 \pm 0.78^{\mathrm{a}}$ & NS \\
\hline \multicolumn{6}{|c|}{$\mathrm{b}^{*}$ coordinate $\left(6^{\circ} \mathrm{C}\right)$} \\
\hline Control melon & $21.69 \pm 0.82^{\mathrm{a}}$ & $19.10 \pm 0.26^{\mathrm{a}}$ & $21.39 \pm 0.35^{\mathrm{a}}$ & $20.68 \pm 0.41^{\mathrm{a}}$ & NS \\
\hline Melon with L. rhamnosus & $20.24 \pm 0.68^{\mathrm{a}}$ & $19.46 \pm 0.42^{\mathrm{a}}$ & $19.53 \pm 0.38^{\mathrm{b}}$ & $19.34 \pm 0.33^{\mathrm{b}}$ & NS \\
\hline \multicolumn{6}{|c|}{$\mathrm{b}^{*}$ coordinate $\left(15^{\circ} \mathrm{C}\right)$} \\
\hline Control melon & $21.69 \pm 0.66^{\mathrm{a}}$ & $22.30 \pm 1.35^{\mathrm{a}}$ & $22.17 \pm 0.73^{\mathrm{a}}$ & $23.17 \pm 1.18^{\mathrm{a}}$ & NS \\
\hline Melon with L. rhamnosus & $20.24 \pm 0.85^{\mathrm{a}}$ & $20.09 \pm 0.98^{\mathrm{a}}$ & $16.47 \pm 0.69^{\mathrm{b}}$ & $17.56 \pm 0.93^{b}$ & NS \\
\hline
\end{tabular}

Means followed by same letter in each column have no statistical difference by Tukey test at $5 \%$ probability. NS: not significant. Source: Elaboration of the authors.

\section{Melon firmness}

A significant difference regarding fruit firmness was observed among treatments stored at 6 and $15^{\circ} \mathrm{C}$, with a linear reduction occurring over time, from 0 to $120 \mathrm{~h}(p<0.05)$ (Table 3$)$. At $6{ }^{\circ} \mathrm{C}$, the firmness decreased from 32.41 to $18.89 \mathrm{~N}$ for the control treatment, while the firmness of minimally processed melon inoculated with $L$. rhamnosus decreased from 19.31 to $16.18 \mathrm{~N}$. On the other 
hand, the control melons stored at $15{ }^{\circ} \mathrm{C}$ presented a decrease in firmness from 32.4 to $5.9 \mathrm{~N}$, while the firmness of minimally processed melon inoculated with L. rhamnosus decreased from 19.3 to $7.1 \mathrm{~N}$.

Table 3. Changes in firmness values as a function of storage time for minimally processed melons inoculated with $L$. rhamnosus HN001 and control.

\begin{tabular}{ccccc}
\hline & \multicolumn{4}{c}{ Firmness (N) } \\
\cline { 2 - 5 } Time (h) & \multicolumn{2}{c}{ Melon with L. rhamnosus } & $6^{\circ} \mathrm{C}$ & Control melon \\
\hline 0 & $6^{\circ} \mathrm{C}$ & $19{ }^{\circ} \mathrm{C}$ & $32.41 \pm 5.24^{\mathrm{aA}}$ & $32.4 \pm 4.25^{\circ \mathrm{aA}}$ \\
48 & $19.31 \pm 3.21^{\mathrm{aB}}$ & $18.64 \pm 5.03^{\mathrm{aB}}$ & $28.96 \pm 7.59^{\mathrm{aA}}$ & $18.66 \pm 4.89^{\mathrm{bB}}$ \\
96 & $18.06 \pm 4.15^{\mathrm{abB}}$ & $10.65 \pm 4.51^{\mathrm{bB}}$ & $17.53 \pm 2.66^{\mathrm{bA}}$ & $5.9 \pm 4.66^{\mathrm{cC}}$ \\
120 & $15.33 \pm 3.73^{\mathrm{bA}}$ & $7.1 \pm 4.69^{\mathrm{bB}}$ & $18.89 \pm 6.57^{\mathrm{bA}}$ & $5.9 \pm 5.73^{\mathrm{cB}}$ \\
\hline
\end{tabular}

Different lowercase letters mean significant difference $(\mathrm{p}<0.05)$ between the times and different capital letters mean significant difference $(\mathrm{p}<0.05)$ between the treatments.

Source: Elaboration of the authors.

The reduction of firmness was an important factor affecting quality of fresh-cut yelow melon fruit during storage. In this study, we observed that after 5 days of storage at $15^{\circ} \mathrm{C}$, minimally processed melon with $L$. rhamnosus had no firmness acceptable for consumption. This can be explained by the action of probiotic bacteria and also the activity of pectinases and polygalacturonases. Thus the action of these enzymes and also the increase in the rate of metabolic processes leads to a limitation on shelf life of the vegetables. Furthermore, the addition of probiotic microorganisms potentiates these effects by the action of microbial enzymes. Therefore, it is suggested the use of alternative / technologies to improve the firmness and prolong the shelf life of these products, such as application of calcium salts, edible coatings, modified atmosphere, among others.

Similar to these results, Rößle et al. (2010a) found that minimally processed apples inoculated with $L$. rhamnous lost their firmness after the second day of storage at $5{ }^{\circ} \mathrm{C}$. They pointed out that this result may be due to the immersion of apple slices in buffer solution containing the probiotic strain, which could induce tissue softening. Supapvanich and Tucker (2011) investigated the cell wall hydrolases in freshcut Honeydew melon fruit during storage at $4 \pm 1{ }^{\circ} \mathrm{C}$ for 5 days. They verified that firmness is a key factor affecting quality of minimally processed Honeydew melon fruit and associates with the increase in polygalacturonase and galactanase activities.

\section{Observation of L. rhamnosus in minimally processed melon by Scanning Electron Microscopy (SEM)}

SEM analysis revealed the presence of several rod-shaped bacteria adhered to the surfaces of minimally processed melon inoculated with $L$. rhamnosus HN001 immediately after processing (Figure $3 \mathrm{~A}$ ) and after $120 \mathrm{~h}$ of storage at $6{ }^{\circ} \mathrm{C}$ (Figure 3B). This results suggest that melon is a promissory substrate for $L$. rhamnosus. No bacterial cell was found in the control treatment (Figure 3C).

Similar to our results, Martins et al. (2013) observed that fruits, such as apple, guava and banana have potential as carriers for probiotic bacteria. The results of scanning electron microscopy showed a positive interaction between the probiotic microorganisms and the fruity tissues, since bacteria strongly adhered to the fruit surface.

According to Oliveira et al. (2011), some steps of minimal processing, such as peeling and cutting, promote the release of intracellular content which is rich in minerals, sugars, vitamins and other 
nutrients, thereby creating ideal conditions for microbial growth. According to Rößle et al. (2010a) this allows the production of vegetal food as a carrier of probiotic microorganisms. Furthermore, according to Soccol et al. (2010), processed fruits and vegetables are considered good food matrices and provide an ideal substrate for probiotic cultures, since they contain minerals, vitamins, antioxidants and fibers.

Figure 3. SEM photomicrograph of minimally processed melon inoculated with L. rhamnosus HN001 (A) immediately after inoculation (0 h), (B) after 120 $\mathrm{h}$ of storage at $6{ }^{\circ} \mathrm{C}$ and $(\mathrm{C})$ without the addition of $L$. rhamnosus $\mathrm{HN} 001$ (control treatment) immediately after processing stored at $6^{\circ} \mathrm{C}$. The arrows indicate that rodshaped bacteria adhered to the vegetal tissue.
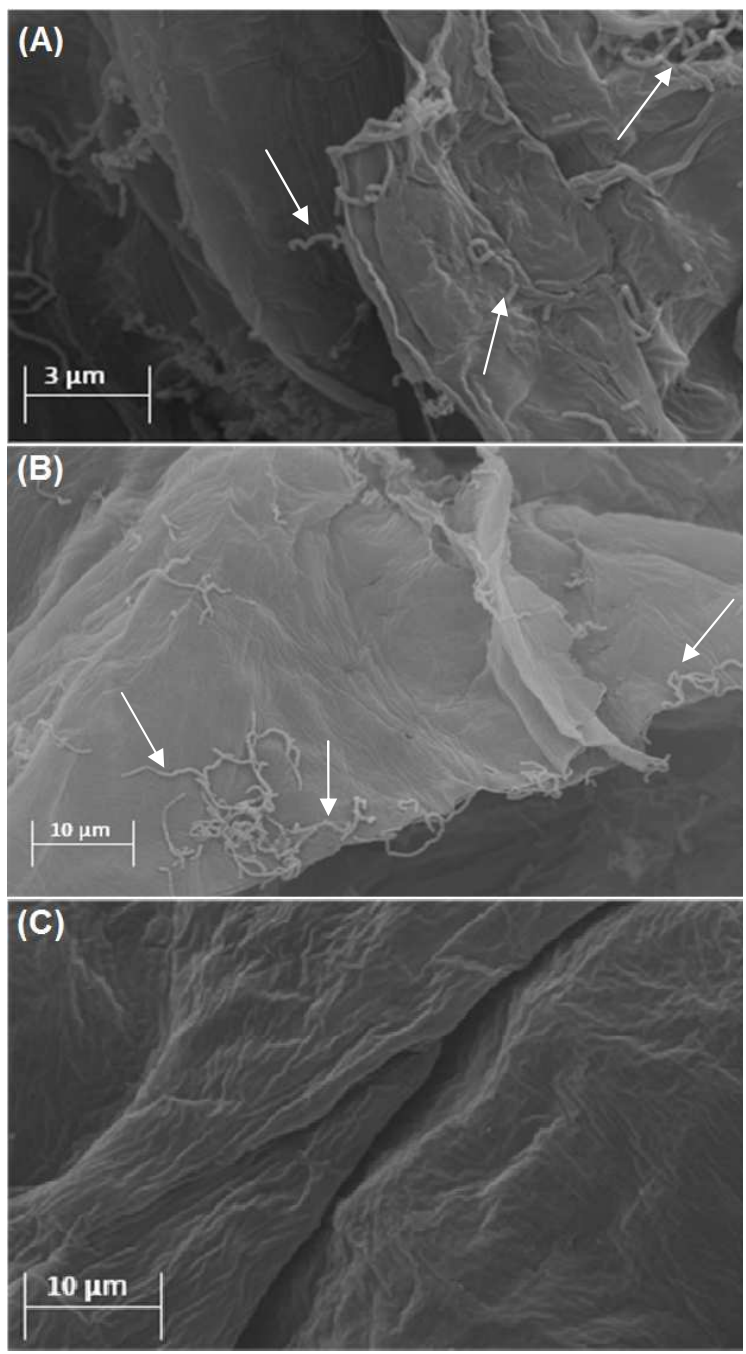

Source: Elaboration of the authors.

\section{Conclusion}

The production of minimally processed melon enriched with L. rhamnosus is feasible, since the probiotic bacterial count was maintained at high levels over the shelf life of the melons. Thus, this fruit has potential for use as a carrier of probiotic bacteria and constitutes an alternative for vegetarians and individuals who have restricted cholesterol diets, lactose intolerance or are allergic to milk proteins present in dairy products. Our previous research has shown that tropical fruits, such as guava, banana and papaya, as well as yacón roots, provide a good substrate for probiotic strains, presenting good adhesion to vegetal tissues.

\section{Acknowledgements}

Our research group gratefully acknowledges the financial support provided by Conselho Nacional de Desenvolvimento Científico e Tecnológico - CNPq.

\section{References}

ALEGRE, I.; VINAS, I.; USALL, J.; ANGUERA, M.; ABADIAS, M. Microbiological and physicochemical quality of fresh-cut apple enriched with the probiotic strain Lactobacillus rhamnosus GG. Food Microbiology, London, v. 28, n. 1, p. 59-66, 2011.

ANDREWS, W. H.; FLOWER, R. S.; SILLIKER, J.; BAILEY, J. S. Salmonella. In: DOWNES, F. P.; ITO, K. (Ed.). Compendium of methods for the microbilological examination of foods. 4. ed. Washington: DC, American Public Health Association, APHA, 2001. p. 357-380.

ASSOCIATION OF OFFICIAL ANALITICAL CHEMISTS - AOAC. Official methods of analysis of the AOAC. Washington, DC, 1997. $850 \mathrm{p}$.

BERNARDEAU, M.; VERNOUX, J. P.; KENRIDUBERNET, S.; GUÉGUEN, M. Safety assessment of dairy microorganisms: The Lactobacillus genus. International Journal of Food Microbiology, London, v. 126, n. 3, p. 278-285, 2008.

BRASIL. Agência Nacional de Vigilância Sanitária. Alimentos com alegações de propriedades funcionais e ou de saúde, novos alimentos/ingredientes, substâncias bioativas e probióticos. IX Lista de alegações de propriedade funcional aprovadas - atualizada em 
julho/2008, Brasília. Disponível em: <http://www. anvisa.gov.br/alimentos/comissoes/tecno_lista_alega. htm>. Acesso em: 27 jan. 2014.

Ministério da Saúde. Agência Nacional de Vigilância Sanitária. Resolução RDC n. ${ }^{\circ} 12$, de 2 de janeiro de 2001. Aprova o Regulamento Técnico sobre Padrões Microbiológicos para Alimentos. Diário Oficial [da] União, Brasília, DF, 10 jan 2001, Seção 1, p. 45-53.

CETIN, B. Production of probiotic mixed pickles (Turşu) and microbiological properties. African Journal of Biotechnology, Nairobi, v. 10, n. 66, p. 14926-14931, 2011.

DAVE, R. I.; SHAH, N. P. Effectiveness of ascorbic acid as an oxygen scavenger in improving viability of probiotic bacteria in yoghurts made with commercial starter cultures. International Dairy Journal, Oxford, v. 7, n. 6-7, p. 435-443, 1997.

FERREIRA, C. L. L. F.; SILVA, A. C. Probióticos e prebióticos na saúde da criança. In: COSTA, N. M. B.; ROSA, C. O. B. (Ed.). Alimentos funcionais: componentes bioativos e efeitos fisiológicos. Rio de Janeiro: Rubio, 2010. p. 97-110.

GIALAMAS, H.; ZINOVIADOU, K. G.; BILIADERIS, C. G.; KOUTSOUMANIS, K. P. Development of a novel bioactive packaging based on the incorporation of Lactobacillus sakei into sodium-caseinate films for controlling Listeria monocytogenes in foods. Food Research International, Amsterdam, v. 43, n. 10, p. 2402-2408, 2010.

KORNACKI, J. L.; JOHNSON, J. L. Enterobacteriaceae, coliforms, and Escherichia coli as quality and safety indicators. In: DOWNES, F. P.; ITO, K. (Ed.). Compendium of methods for the microbiological examination of foods. Washington, DC: American Public Health Association/APHA, 2001. p. 69-82.

MARK-HERBERT, C. Innovation of a new product category - functional foods. Technovation, Ottawa, v. 24, n. 9, p. 713-719, 2004.

MARTINS, E. M. F.; RAMOS, A. M.; VANZELA, E. S. L.; STRINGHETA, P. C.; OLIVEIRA PINTO, C. L.; MARTINS, J. M. Products of vegetable origin: a new alternative for the consumption of probiotic bacteria. Food Research International, Amsterdam, v. 51, n. 2, p. 764-770, 2013.

NICOLAIS, V.; RUSSO M.; BARBIERI, G.; RASTRELLI, L. Quality evaluation on processed melons (Cucumis melo L.) packaged in protective atmosphere. Emirates Journal of Food and Agriculture, Abu Dhabi, v. 23 , n. 6, p. 525-532, 2011.
OLIVEIRA, M. A.; SOUZA, V. M.; BERGAMINI, A. M. M.; MARTINIS, E. C. P. Microbiological quality of ready-to-eat minimally processed vegetables consumed in Brazil. Food Control, Oxford, v. 22, n. 8, p. 14001403, 2011.

OMS-OLIU, G.; SOLIVA-FORTUNY, R. Future trends in fresh-cut fruit and vegetable processing. In: MARTÍNBELLOSO, O.; SOLIVA-FORTUNY, R. (Ed.). Advances in fresh-cut fruits and vegetables processing. Boca Raton: CRC Press, 2011. p. 377-386.

PADMAJA, G. A.; RAMACHANDRA, B.; MANJUNATH, H.; PRABHA, R.; KRISHNA, R.; SHANKAR, P. A. Characterization of lactic acid bacteria isolated from fruits and vegetables for their antibacterial activity. Journal of Dairying, Foods and Home Sciences, Bangalore, v. 30, n. 2, p. 85-89, 2011.

PERES, C. M.; PERES, C.; HERNÁNDEZ-MENDOZA, A.; MALCATA, F. X. Review on fermented plant materials as carriers and sources of potentially probiotic lactic acid bacteria - with an emphasis on table olives. Trends in Food Science \& Technology, London, v. 26, n. 1, p. 31-42, 2012.

RANADHEERA, R. D. C. S.; BAINES, S. K.; ADAMS, M. C. Importance of food in probiotic efficacy. Food Research International, Amsterdam, v. 43, n. 1, p. 1-7, 2010.

RIVERA-ESPINOZA，Y.; GALLARDO-NAVARRO, Y. Non-dairy probiotic Products. Food Microbiology, London, v. 27, n. 1, p. 1-11, 2010.

RODGERS, S. Novel applications of live bacteria in food services: probiotics and protective cultures. Trends in Food Science \& Technology, London, v. 19, n. 4, p. 188-197, 2008.

ROJAS-GRAÜ, M. A.; SOLIVA-FORTUNY, R.; MARTIN-BELLOSO, O. Edible coatings to incorporate active ingredients to fresh cut fruits: a review. Trends in Food Science \& Technology, London, v. 20, n. 10, p. 438447, 2009.

RÖßLE, C.; AUTY, M. A. E.; BRUNTON, N.; GORMLEY, R. T.; BUTLER, F. Evaluation of fresh-cut apple slices enriched with probiotic bacteria. Innovative Food Science and Emerging Technologies, Oxford, v. 11, n. 1, p. 203-209, 2010a.

RÖßLE, C.; BRUNTON, N.; GORMLEY, R. T.; ROSS, P. R.; BUTLER, F. Development of potentially symbiotic fresh-cut apple slices. Journal of Functional Foods, St. John's, v. 2, n. 4, p. 245-254, 2010 b.

SAAD, S. M. I. Probióticos e prebióticos: o estado da arte. Brazilian Journal of Pharmaceutical Sciences, São Paulo, v. 42, n. 1, p. 1-16, 2006. 
SAAD, S. M. I.; BEDANI, R.; MAMIZUKA, E. M. Benefícios à saúde dos probióticos e prebióticos. In: SAAD, S. M. I.; CRUZ, A. G.; FARIA, J. A. F. (Ed.). Probióticos e prebióticos em alimentos: fundamentos e aplicações tecnológicas. São Paulo: Varela, 2011. cap. 2, p. 51-84.

SALMINEN, S.; VON WRIGH, A. Lactic acid bacteria: microbiology and functional aspects. New York: Marcel Dekker Inc, 1998. 601 p.

SILVA, S. R. P.; VERDIN, S. E. F.; PEREIRA, D. C.; SCHATKOSKI, A. M.; ROTT, M. B.; CORÇÃO, G. Microbiological quality of minimally processed vegetables sold in Porto Alegre, Brazil. Brazilian Journal of Microbiology, São Paulo, v. 38, n. 4, p. 594-598, 2007.

SOCCOL, C. R.; VANDENBERGHE, L. P. S.; SPIER, M. R.; MEDEIROS, A. B. P.; YAMAGUISHI, C. T.; LINDNER, J. D.; PANDEY, A.; SOCCOL, V. T. The Potential of probiotics: a review. Food Technology and Biotechnology, Zagreb, v. 48, n. 4, p. 413-434, 2010.

SUPAPVANICH, S.; TUCKER, G. A. Physicochemical changes in fresh-cut Honeydew melon fruit during storage. African Journal of Biotechnology, Nairobi, v. 6, n. 12 , p. 2737-2742, 2011.
WU, Z. S.; ZHANG, M.; WANG, S. J. Effects of highpressure argon and nitrogen treatments on respiration, browning and antioxidant potential of minimally processed pineapples during shelf life. Journal of the Science of Food and Agriculture, London, v. 92, n. 11, p. 2250-2259, 2012.

YOON, K. Y.; WOODAMS, E. E.; HANG, Y. D. Probiotication of tomato juice by lactic acid bacteria. Journal of Microbiology, Seoul, v. 42, n. 4, p. 315-318, 2004.

YU, Z. H.; ZHANG, X.; LI, S. Y.; LI, C. Y.; LI, D.; YANG, Z. N. In vitro evaluation of probiotic properties of Lactobacillus plantarum strains isolated from Chinese Sauerkraut. African Journal of Biotechnology, Nairobi, v. 11, n. 21, p. 4868-4875, 2012.

ZHANG, Y.; ZHANG, L.; DU, M.; YI, H.; GUO, C.; TUO, Y.; HAN, X.; LI, J.; ZHANG, L.; YANG, L. Antimicrobial activity against Shigella sonnei and probiotic properties of wild lactobacilli from fermented food. Microbiological Research, Copenhagen, v. 167, n. 1, p. 27-31, 2011. 
